\title{
UMA NOVA FORMA DE GERENCIAMENTO: A AVALIAÇÃO'
}

\author{
Jean-Pierre Faguer* \\ Gabrielle Balazs
}

SÍNTESE - A partir de entrevistas realizadas numa empresa de informática em momentos diferentes, dos anos oitenta aos anos noventa, junto a vários agentes que trabalhavam nesse local, este artigo expỏe como, atrás das relações de trabalho aparentemente descontraidas, a busca pela "transparência" obriga cada um dos assalariados a trabalhar sob o olhar dos outros, e as avaliações constantes dos desempenhos são indicadores de tensões que suscita a intensificação da concorrência. Também é exigido do pessoal subalterno uma parte cada vez maior de atividade e de "comunicação". Enfim, verifica-se que as relações de trabalho são inseparavelmente relações de dominação, onde cada posto, ao mesmo tempo que implica o domínio de uma competência técnica específica, demanda as qualidades ordinariamente exigidas do pessoal de serviço.
ABSTRACT - The present article is based on a series of interviews held in a computer company during the 1980s and 90s with several employees from different levels. It shows that, behind apparently relaxed workplace relations, the concem for "transparency", which obliges every employee to work under the watchful eye of everyone else, and the ongoing evaluation of individual performance are indicative of the tensions created by the intensification of competition. Even the junior employees are required to devote more and more time to service and "communication". Relations in the workplace are inseparable from relations of domination, where every job implies mastering a specific technical skill but also calls for qualites normally demanded of personnel in the service sector.

O controle permanente dos desempenhos tende a se instaurar hoje em todos os locais de trabalho, nas fábricas, nos escritórios, nos supermercados e também nos empregos subalternos da atividade intelectual e da mídia. A incerteza ligada com muita freqüência a estas formas de atividade obriga a investir e desinvestir continuamente, mobiliza, ao mesmo tempo, a crença no futuro e a ameaça de

\footnotetext{
- Artigo publicado originalmente em Actes de la Recherche en Sciences Sociales, Paris: Seuil, n. 114, set/1996, p. 68 a 78. Tradução: Vanise Pereira Dresch; Revisão técnica: Julieta Beatriz Ramos Desaulniers.

- Professor e Pesquisador junto ao Centre d'Études de l'Emploi e Maison des Sciences d l'Homme Paris/França. E-mail: faguer@msh-paris.fr

-' Professora e Pesquisadora junto ao Centre d'Études de l'Emploi e Collège de France - Paris/França.
}

\begin{tabular}{|l|l|l|l|l|l|}
\hline VERITAS & Porto Alegre & v. 42 & $\mathrm{n}^{\circ} 2$ & Junho 1997 & p. 411-426 \\
\hline
\end{tabular}


perder o seu emprego. A disponibilidade e a flexibilidade suscitam auto-avaliação e reconversão. As relações de trabalho são inseparavelmente relações de dominação, onde cada posto, ao mesmo tempo que implica o domínio de uma competência técnica específica, requer as qualidades exigidas ordinariamente de um profissional de serviço.

Assim, com a informática, exige-se até do pessoal subalterno uma parte cada vez mais importante de atividade de serviço e de "comunicação". Tornando-se aparentemente mais autônomo, cada assalariado deve acumular as qualidades contraditórias implicadas no domínio técnico do posto e na consideração das relações entre colegas, assumindo inclusive tarefas de enquadramento. Cada um deve saber negociar o seu trabalho, auto-avaliar-se, "vender-se".

Uma empresa de alta tecnologia, assim como todas as empresas de produtos culturais - editora, jornal, emissora de televisão, grande loja especializada em discos, livros ou espetáculos, casa de alta costura, etc. - aparece como um espaço onde a aptidão para teatralizar a apresentação de si é um trunfo essencial para o sucesso de sua carreira. Nesse universo que recruta um pessoal jovem, o corpo é um capital que deve ser conservado, desenvolvido e mantido. A manutenção do corpo "em forma" é um trabalho dispendioso, cansativo, uma ascese a que ninguém pode escapar. Mas tudo indica que se trata de uma aptidão que é distribuida de modo muito desigual, de acordo com a origem social ou o sexo, na medida em que o controle das expressões corporais ou das emoções, que se aprende desde a primeira infância, é um indício particularmente seletivo da origem de classe. Parece, no entanto, que as mulheres de origem operária conseguem melhor se apropriar destas novas formas de "espírito da casa" do que os homens que têm a mesma trajetónia social. Tudo aquilo que lembra os atributos de operários é rejeitado por ser arcaico. Os operários vestidos com macacão de trabalho, que insultam e xingam seus superiores - comportamento freqüente numa empresa comum não têm lugar aí. Tais formas de luta são imediatamente desqualificadas, num ambiente que é feito justamente para eufemizar tudo aquilo que evoque situações conflituosas ou a vulgaridade.

O que se propõe aos executivos que se fazem na empresa, através da avaliação contínua dos desempenhos, refere-se mais a princípios de vida que engajam implicitamente o futuro de toda a família, do que a um plano de carreira. Num período em que as possibilidades de promoção social estão freadas pela situação do mercado de trabalho, tais empresas podem surgir como substitutas da escola. É o caso das atividades culturais, esportivas, em particular em férias e finais de semana, mas, sobretudo, das atividades de sociabilidade ligadas ao exercício da profissão: missões e postos no Exterior, possibilidades de moradia em cidades universitánias, ricas em equipamentos escolares ou em possibilidades lingüísticas que são também condições de acesso ao estilo de vida e aos instrumentos de reprodução social das camadas médias. 


\section{Trabalhar na urgência}

Na empresa de informática observada ${ }^{i}$ onde as relações de trabalho são aparentemente sem tensão, a preocupação com a transparência que obriga cada um dos assalariados a trabalhar sob o olhar dos outros, a passagem dos horários livres aos horários fixos, e, para uma parte do pessoal, ao trabalho noturno, a avaliação constante dos desempenhos, que não se limita à avaliação anual ou à divulgação dos resultados obtidos por cada equipe, são indicadores da tensão que a intensificação da concorrência suscita.

Esta filial de uma multinacional instalada em Grenoble, no início dos anos setenta, fundada perto de São Francisco em 1939, caracteriza-se por uma proporção de executivos e de engenheiros sensivelmente mais elevada do que a das outras empresas da região, sendo a maior parte do trabalho de produção subcontratado. $\mathrm{O}$ que parece definir os produtos sofisticados, como aqueles da informática, é o importante papel da relação com a clientela, sobretudo no que concerne à manutenção, que leva a unir estreitamente, num mesmo espaço, concepção, produção e comercialização dos produtos. ${ }^{2} \mathrm{O}$ essencial do trabalho operário (conforme um relatório do departamento de pessoal, em 1990, os operários representavam $22 \%$ dos efetivos contra $44 \%$ de engenheiros e gerentes ${ }^{3}$ ) é consagrado à montagem e ao controle de qualidade dos produtos. Amplamente majoritárias dentre os funcionários (81\%), as mulheres são tão numerosas quanto os homens nos empregos de operários (50\%); mas elas ocupam somente $23 \%$ dos empregos reservados a engenheiros e gerentes.

No setor da informática, a renovação dos produtos é constante e implica um ciclo de produção cada vez mais curto, e a busca da inovação estimula uma intensificação do ritmo de trabalho. Neste mercado, que tende a ser o exemplo mais bem-sucedido de um mercado mundial, a busca da qualidade e a do lucro estão cada vez mais estreitamente ligadas (retorno à produção em série, trabalho noturno, redução dos horários "flexíveis", busca constante da baixa dos custos de produção...). O gerenciamento por objetivos se apóia na busca da qualidade. Tudo se passa como se a autoridade estivesse diluida em todos os niveis do pessoal, incluindo os subalternos: cada supervisor que, aliás, não tem este cargo garantido por toda a vida, é, por sua vez, submetido à autoridade de um outro supervisor; ainda, cada supervisionado pode recorrer ao supervisor de seu supervisor.

Durante os anos setenta, o crescimento foi rápido, os efetivos passaram de uma centena de assalariados a cerca de dois mil. A maioria deles admitidos em início de vida ativa, os assalariadas envelheceram progressivamente junto. Os efeitos da idade são ainda mais sentidos por virem acompanhados pelo abandono

1 Este artigo se apóia em entrevistas realizadas em diferentes momentos desde 1977, no decorrer de uma série de enquetes conduzidas pelo Centro de Estudos do Emprego, junto a agentes da área da produção, técnicos, altos funcionários, supervisores e representantes sindicais, membros do comitê da empresa, redatores do jornal da empresa, pessoal médico, enfim os representantes do serviço de pessoal e do serviço de formação.

2 Um segundo estabelecimento, mais centrado na produção, foi criado depois na região de Lyon.

3 Relatório de igualdade profissional entre os homens e as mulheres referente ao ano fiscal de 1990, Departamento de pessoal, março/1991. 
da gestão "humanista" à qual os operários estavam muito ligados - principalmente as mulheres - recrutados dentre o pessoal demitido das empresas regionais de setores em declínio" (têxtil, alimentação, etc.). Nos anos oitenta, os operários e os funcionários descobriram coletivamente os problemas ligados à constituição e ao envelhecimento das familias: licenças de maternidade, absenteísmo ligado ao atendimento das crianças de pouca idade, divórcio. Como a maioria dos grupos altamente escolarizados, é um pessoal que retardou o calendário dos nascimentos. A maioria das mulheres teve seu primeiro filho somente depois dos trinta anos. Se todos os assalariados começaram sua carreira profissional solteiros, o sentido que se deve dar a esta forma de celibato provisório é diferente para os homens e para as mulheres. Para estas, é provável que a contratação não pudesse ter ocorrido se fossem mães de crianças pequenas.

$\mathrm{O}$ que nos interessou nesta pesquisa se refere menos a um estudo preciso dos postos do que às trajetórias de assalaniados definidas por um conjunto de variáveis que as categorias consideradas nas estatísticas do mercado de trabalho não levam em conta. Em primeiro lugar, a maior parte do pessoal não é oriunda da região. Recrutados num mercado nacional e mesmo internacional - recrutamento facilitado por estreitos laços da empresa com o mundo escolar ${ }^{5}$ os assalariados têm poucos vínculos de familia ou de amizade com a população local. Em segundo lugar, mesmo que uma parte dentre eles ocupe postos que exigem diplomas mais elevados do que aqueles que possuem, eles estão longe de ser autodidatas, de acordo com a idéia que se tem habitualmente dos executivos que se fazem na empresa. Ao contrário, todos aqueles que tivemos a ocasião de encontrar tinham boa formação escolar, inclusive de nivel superior. Os responsáveis pelo recrutamento insistem na importância maior que atribuem às competências escolares que permitem "evoluir" (o potencial) do que aos diplomas. Enfim, as características "individuais" ligadas a engajamentos cívicos e a investimentos culturais, associativos ou religiosos, um bom conhecimento do inglês falado desempenharam, para cada um deles, um papel importante.

\section{A empresa vista através da enfermaria}

O espírito da empresa é visivel logo na entrada do estabelecimento. A voz, a postura são trabalhadas como se qualquer relaxamento corporal fosse o sinal de um relaxamento moral. $\mathrm{Na}$ recepção, o tom é dado pelos alto-falantes cujas mensagens, em inglês e em francês, evocam as vozes de aeroportos. As telefonistas são ao mesmo tempo recepcionistas e recebem os visitantes - clientes, fornecedores, representantes comerciais, funcionários de outras empresas, etc. - anotando seus nomes, o da companhia que representam, a hora de chegada, e lhes dão

4 O caso mais conhecido é aquele dos operários dos estabelecimentos Lou, onde o pessoal demitido ocupa a usina por vários meses. Sobre esse tema, cf. Pierre Frappat, Le Mythe blessé, Grenoble, Arthaud, 1979.

- Sobre os laços estabelecidos pela empresa com os estabelecimentos escolares de Grenoble, principalmente através de propostas de estágios, empréstimos de material informático, convençōes de parcerias, etc., cf. Gabrielle Balazs et Jean-Pierre Faguer, Cahier 32 du Centre d'études de l'emploi, Paris, PUF, 1989, cap. II, "La politique locale des liens entre l'école et les entreprises". 
um crachá. Os controles se operam, assim, de maneira discreta. Para elas, o essencial está na postura e na eficácia (apesar de numerosas chamadas telefônicas, do grande número de visitantes e da passagem rápida da língua francesa à inglesa, nunca se deve correr ou elevar o tom). O trabalho e o esforço não devem ser percebidos pelos que vêm de fora. Não se deve dar sinais de irritação ou de cansaço. A organização do espaço (arranjos florais, exposição de produtos em vitrines, salas de recepção com algumas obras de arte) e o modo do pessoal agir com os visitantes fazem sentir, desde a entrada, que se está num universo distante não apenas daquele da empresa industrial tradicional, mas também daquele da função pública. Mesmo entre colegas, a descontração não deve se transformar em familiaridade. É preciso saber manter distância, o que um ambiente de alta tecnologia (correio eletrônico, microcomputador em cada sala, etc.) facilita.

Como observa uma das funcionárias: "Não se pode ser excepcional trezentos e sessenta e cinco dias por ano. Observem as avaliações dos desempenhos, eles chegaram até mesmo a nos enquadrar: é aceitável, bom ou muito bom, chegam ao último nível onde as pessoas são excepcionais. Eu lhes disse: Esperem aí, isso é uma brincadeira! Excepcional, a gente é excepcional uma vez de tempos em tempos, [...]. Eu sei lá, num restaurante, um dia você diz ao chef: Ah! tua comida estava excepcional hoje! porque, bom, ele teve um dia, aquele dia, foi a genialidade do dia. Eu digo: Mas, enfim, excepcional trezentos e sessenta e cinco dias do ano, não é aceitável, não é possível, portanto não deveria ter ninguém! $\mathrm{E}$ tem pessoas que estão no nível do excepcional".

As tensões podem ser tanto mais intensas por ser preciso trabalhar num ambiente jovem, esportivo, onde a competição profissional é inseparável do culto do corpo. ${ }^{\circ}$ Um conjunto de atividades são propostas no horário do almoço ou durante os fins de semana e as férias: stretching, escaladas, tênis (uma parede de escalada e quadras de tênis foram construídas na fábrica), e o pessoal, mesmo os operários, cuidam de sua forma física, dedicando-se a atividades esportivas consideradas como atividades de formação permanente, entre outras. $O$ trabalho com o corpo tem também uma dimensão moral; o esforço para dominá-lo, o controle das emoÇões são expressões do projeto de ascensão social. O vestuário, geralmente práti$\mathrm{co}$, a postura física, as atitudes descontraídas referem-se a exigências de saúde, de gosto pela natureza e pelo lazer sadio, que estão em afinidade com a representação, nas imagens publicitárias, do corpo dos executivos.

A enfermaria é um dos únicos lugares onde os assalariados podem se subtrair momentaneamente à pressão que é exercida sobre eles e deixar provisoriamente de se fiscalizarem. Num escritório, você está com dois ou três, você desaba com dois ou três; se você cai em produção ou se você começa a gritar porque tem uma crise de nervos, o prédio inteiro pára e olha, são as cabeças que surgem de cima das divisórias e dizem: "Ei, o que está acontecendo?". Não se deve esquecer que as tensões são ainda mais fortes porque o mercado de trabalho, mesmo na eletrônica, tem se tornado progressivamente mais seletivo. Os assalariados interiorizaram tanto mais o medo do desemprego por verem em torno deles cada vez mais

As publicidades recentes que têm aparecido na grande imprensa para contratar engenheiros e técnicos insistem no ambiente califomiano e nos valores dos anos sessenta da empresa. 
trabalhadores interinos ou com contrato temporário, enquanto um número cada vez mais significativo de tarefas é confiado a empresas externas.

Os sinais clínicos levantados pelo pessoal médico são numerosos: o absenteísmo e as interrupções de trabalho, que provêm sobretudo das mulheres, desde que os horários passaram a ser fixos, os assalariados que vêm "explodir" na enfermaria, o desgaste dos executivos que ameaça, na verdade, todos os assalariados, enfim, as depressões e as doenças prolongadas.

De acordo com uma das enfermeiras, os funcionários recorrem muito a licenças de saúde, por depressão, a lista de medicamentos a serem tomados é composta de antidepressivos, e há um mal-estar geral:

“É o problema da empresa, a partir do momento em que você não está bem, é preciso ter,
ao menos, uma base familiar ou uma vida pessoal sólida. Se, por acaso, se peca um pouco
por este lado, geralmente a gente vê as pessoas decairem algum tempo depois, ao nivel do
trabalho, não funciona mais porque, efetivamente, elas sofrem tanta pressão ao nível de seu
trabalho, se não tiverem uma compensação fora ou algo que as renove, que lhes faça bem,
é o fim, é o desmoronamento [...] não tem nenhuma estrutura (para atendê-los), oficial-
mente, isso não existe. Em contrapartida, então, se vê com muita freqüência os superviso-
res, diretamente, que assumem a responsabilidade das coisas e, então, nós, do serviço mé-
dico, damos saltos quando eles vêm nos contar certas coísas [...], sei lá, pessoas que come-
çam a assumir praticamente o divórcio de um de seus funcionários." [...] "Há executivos
que vêm de Paris, por exemplo, X, olhem em que estado o deixaram. Competitivo até a
aposentadoria, infarto no aeroporto de Washington, e ele ainda está ai, trabalha meio turno,
mas acho que é alguém que realmente dá sua vida até o fim pela HP. É o antigo diretor
de.... Ele trabalha com moderação agora. Eu diria que ele dá sua vida mesmo assim, com
parcimônia agora, ou seja, seu incidente fez com que, logo depois, ele dissesse: "Ah, agora
chega! Eu quase morri, não, não continuo mais", isto é, em 48 horas, ele pediu sua demis-
são da alta direção e lhes disse: "Vocês me achem outra coisa, não quero morrer num avi-
ão!"

Ao mesmo tempo dentro e fora da empresa (ela é uma assalariada entre outras, submetida aos mesmos horários, ao mesmo ambiente de trabalho, aos mesmos critérios de avaliação), a enfermeira, cuja entrevista retranscrevemos em parte aqui, deve a essa posição na fronteira bem como à sua trajetória esta visão um pouco distante que faz dela um informante sensivel aos efeitos patológicos de um espirito da casa, ao qual ela não pode totalmente aderir. Filha de um antigo operário que se tornou executivo numa importante empresa local, casada com um engenheiro, mãe de uma criança, ela foi admitida, após diversas experiências profissionais, das quais 5 anos na região parisiense, com a esperança de encontrar enfim condições de trabalho mais compativeis com sua vida familiar ("eu tinha boas propostas, principalmente a da Prison de la Santé"); seus primeiros empregos são estressantes: um posto noturno em serviço de reanimação, um trabalho junto a pessoas da quarta idade, uma substituição como enfermeira num canteiro de obras. Representante do pessoal, esta mulher, que faz teatro durante suas horas livres, tem, no entanto, um ponto de vista sobre a empresa que se deve muito à posição que ela ocupa nos únicos bastidores de um lugar de trabalho onde a autoapresentação faz parte da definição "no estado prático" (aquela que não se encontra nos regulamentos internos, nem na descrição dos "perfis de cargos") da competência profissional. 
"Se recebemos, na verdade, tanta gente na enfermaria, é porque a enfermaria é um dos raros lugares fechados. Uma vez, vi alguém receber uma ligação telefônica: sua avó doente, muito doente, e logo começou a ter os olhos cheios de lágrimas; havia vinte pessoas em volta, que não fizeram por mal, eu diria que isso faz parte do ser humano, você sente que alguém recebeu um telefonema não muito bom, as coisas não vão bem, e todo o mundo parou de falar. Conclusão: você não se desata em soluços no telefone, você se abstém, você se retém até passar pela porta da enfermaria, depois é lá que explode porque se precisa disso de vez em quando. [...]

Temos um pequeno sistema na enfermaria que vale pelo que é, porque, como estamos numa equipe e não podemos propor grande coisa às pessoas, quando vemos que as pessoas estão paradas, depois de três semanas, um mês, enviamos a elas uma cartinha de contato, na qual colocamos: Bem, escute, você está parado desde o dia tal..., se você precisar, gostariamos muito de ter notícias suas, se você precisar, entre em contato." A enfermeira que eu substitui gostaria muito de ter chegado a ter o estatuto de assistente social, ela fazia a parte social, ela atendia as pessoas, era alguém que tinha um dinamismo fantástico. Ela telefonava para as pessoas, fazia isso porque era antiga na casa e porque, enfim, conhecia praticamente todo o mundo. Quando ela havia entrado, eram uns cem, portanto, era uma pequena familia. Eu cheguei, ela me disse: "Você entende, às vezes telefono, me dei mal uma ou duas vezes, teve gente que me disse: o que é? por que .o serviço médico? você está se certificando de que eu estou mesmo doente? E isso pode ser visto assim, como um controle." Então agora, decidimos: "uma cartinha com duas ou três frases, se você quiser, chame, se näo quiser...".

$-\mathrm{E}$ depois, se isso continua?

- Na maioria dos casos, as pessoas nos telefonam dizendo: "Estou realmente muito contente, tenho a impressão de que alguém... vocês não estão me esquecendo completamente." Infelizmente, o problema é que não podemos fazer mais do que isso. Eu me pergunto, e um dia, vai nos acontecer que a pessoa vai realmente nos telefonar dizendo: "Sim, tenho um grande problema, venham me ver!" $\mathrm{E}$ não sei como vamos fazer.

- Você dizia que tinha ligações privilegiadas com médicos da cidade, que tipo de médicos? psiquiatras, clínicos gerais?

- Então, no início, eu enviava... O psiquiatra, primeiro, na França, é contudo mal visto, ir dizer a alguém: "Ouça, você deveria ir consultar um psiquiatra, isso the faria bem", geralmente, é um pouco... agora, propor-lhe... a gente tenta enviar para clínicos gerais, clínicos gerais que dispõem de tempo. Um bom generalista que dispõe de uma hora para tentar compreender um pouquinho, bom, já é um verdadeiro passo, e talvez, em seu consultónio, através dele, as pessoas conseguiram melhorar lá fora. $\mathrm{E}$ depois, é verdade também que os psiquiatras, eu conhecia alguns através do serviço de recrutamento, porque o pessoal do recrutamento fez psicologia inicialmente, portanto, eles têm conhecimentos nesta área, é verdade que eles conhecem pessoas que certamente são boas, que the ajudam, mas que são excessivamente caras e que, para alguém que trabalha, por exemplo, na produção, eu diria que é quase impossivel, se isso deve lhe custar 600,00 francos $(120,00$ dolares) por semana, eu não vejo como alguém da produção possa gastar isso [...]. Em muitos casos, é uma coisinha que não vai bem num momento, precisaria de um empurrão apenas e de alguém que the esclarecesse um pouco o problema, que o visse de fora e que lhe dissesse: "Ouça, bom, talvez seja isso e aquilo as coisas que devem ser trabalhadas", e depois, essas pessoas são psicoterapeutas, que não são reconhecidos pela previdência social, é um problema...

- E nunca lhe aconteceu de recorrer a um serviço de urgência psiquiátrica? pessoas que realmente desmoronam?

- Duas vezes, sim, duas vezes [...] então, não é um serviço de urgência psiquiátrica, chamamos o SAMU (Serviço de Atendimento Médico de Urgência). Tivemos uma vez, foi minha colega da noite que atendeu isso, alguém que estava muito deprimido e que seu psiquiatra mesmo assim - porque a teoria atual, eles não estão errados, é verdade que se alguém está muito deprimido, há um momento em que se tenta fazê-lo voltar ao trabalho mesmo assim, porque se sabe muito bem que as pessoas, em casa, andam em círculos e 
não conseguem sair disso, e depois, era alguém que estava sob um tratamento muito forte, teve que dobrar seus medicamentos porque não estava bem e tinha que suportar novamente, contudo, a pressão da HP, que, apesar de tudo, está aí, e então, ele chegou à enfermaria num estado, estava quase delirando; como não há serviço de urgência psiquiátrica em Grenoble, temos que transferir tudo para o "42-4242". É o SAMU. Eles estão bem preparados para este tipo de coisas. [...] Por último, tivemos uma garota do restaurante que, também, tinha tomado medicamentos, devia tomar meio comprimido, acho eu, por dia, ela havia tomado seis. Ela não era realmente um problema para nós, ela dormia. Não podiamos, contudo, deixá-la dormir o dia inteiro na enfermaria controlando-a a cada quinze minutos! isso nos parecia bastante pesado."

\section{Controle e cumplicidade}

A confiança constitui um dos componentes da qualificação profissional de um pessoal intermediário cuja função essencial consiste em estabelecer o vinculo, em "comunicar". Qualquer transmissão de informação, mesmo pessoal, "para fora" pode ter conseqüências sobre a imagem da empresa; entendida como comportamento inadmissivel, embora não mencionado no regulamento interno, ela corre 0 risco de ser considerada, em muitos sentidos, um erro profissional. Assim, para esta sondagem, os assalariados só desejavam responder sob a condição de que seu supervisor, ou um membro da direção, fosse informado previamente dos objetivos da pesquisa e lhes desse a autorização de participar dela. As hesitações e as várias recusas de entrevistas contrastavam com o tom aparentemente livre que existe entre a hierarquia e o pessoal: presença de executivos de alto nível nos mesmos prédios, funcionários separados em salas envidraçadas que expõem cada um a trabalhar sob o olhar dos colegas e dos chefes, tratamento por "tu" (em francês, tratamento informal como "tu" ou "você" em português), rituais de integração como o "intervalo para o croissant" de manhã, os drinks para comemorar os sucessos de uma equipe quando um objetivo é alcançado, liberdade de circulação dentro dos prédios ou de reunião.

Os responsáveis pelas relações públicas controlam tanto as informações ligadas aos produtos e a sua fabricação quanto aquelas que estão ligadas às relações do pessoal e à imagem da empresa que pode ser, através deles, veiculada externamente. Enquanto um horário havia sido marcado de Paris com uma secretária, durante as horas de trabalho, esta chegou à recepção acompanhada pelo diretor de relações públicas que veio tomar informações sobre nossos objetivos, com a preocupação de reverter deliberadamente a situação de enquête.

\section{O SISTEMA "PORTA ABERTA"}

"Aqui, é o método US, é o sistema "porta aberta": você tem um problema, bem, você não fica na sua cadeira, você vai falar imediatamente com o chefe. $O$ chefe ou outra pessoa. Mas todo o mundo deve recebê-lo e estar disponível porque, se você vai lá, é porque normalmente justifica. Há dois dias, eu disse ao meu chefão: temos realmente que conversar. Ele se levantou e nós nos sentamos numa mesa, no entanto, ele estava mergulhado no trabalho. $\mathrm{E}$ então ele me disse: "É preciso estar disponivel", este é o seu trabalho; isso faz parte de seus objetivos. É preciso saber se virar, é preciso que ele esteja lá." (Técnica de manutenção, nivel baccalauréat, supervisora, representante do pessoal).

Seria necessário descrever também, ao mesmo tempo, os rituais de integração e os sistemas de auto-avaliação aplicados por supervisores mais próximos de con- 
selheiros psicológicos que de contramestres, o leque das técnicas sociais de enquadramento que conduzem ao superinvestimento dos assalariados. Este modelo de gerenciamento é a tal ponto interiorizado que ele perdura apesar das transformações recentes de um trabalho que se tornou mais diretivo ${ }^{7}$ para o pessoal operário por causa da crise (recurso ao trabalho noturno, mesmo para as mulheres, e a um modo de trabalho tayloriano para linhas de produção).

Se os princípios de avaliação de seus subordinados são comuns a todos os supervisores, a percepção dos problemas, os limites de intervenção variam principalmente, pelo que parece, de acordo com a maneira como eles "subiram" na empresa. Dois percursos nos parecem exemplares desse processo de vinculação com a empresa e de adesão a seu modo de gestão. Dois supervisores, ambos oriundos das camadas médias, têm, no entanto, uma experiência diferente, "no masculino e no feminino", do exercício da autoridade. O homem é titular de um baccalauréat em literatura (ele nos tinha sido apresentado como um exemplo positivo de diplomado em literatura capaz de conseguir sua reconversão numa empresa cujo capital profissional é de base científica) obtido numa reputada escola de ensino privado da região parisiense; ele pensa que sua função requer, em qualquer ocasião, manter distância de seus subordinados: "Se o desempenho cai, creio que o que devemos fazer é constatar que efetivamente ele está caindo. As pessoas começam a cometer erros, não estão mais ligadas em seu trabalho, acho que é preciso fazer com que compreendam que estamos vendo que, efetivamente, há uma queda de desempenho, que isso não é aceitável, não é normal; isso me aconteceu, há seis ou oito meses, com uma funcionária, eu disse a ela: "Ouça, OK", ela me falou de seu problema, eu sabia o que estava acontecendo, eu disse: "OK, seu desempenho, assim não dá, bom, não levo isso em conta para esta avaliação, esqueço estes três meses, mas agora, é preciso que isso se resolva bem depressa, porque não poderá durar eternamente assim" [...]; temos, talvez, tendência a ter uma certa piedade, e isso não funciona, é realmente um desastre. [...] Não devemos de forma alguma envolver-nos com os problemas pessoais porque isso é o fracasso garantido."

A mulher entrevistada, filha de pequenos comerciantes da região, admitida com 18 anos como operadora na produção, com apenas um CAP (certificado de aptidão profissional) de estabelecimento de ensino público, tendo se tornado supervisora após ter sido assistente técnica, esforça-se, ao contrário, para exercer sua autoridade na proximidade e na cumplicidade. Antiga auxiliar de enfermagem, depois operária numa indústria de alimentação, ela compartilha a mesma história profissional das mulheres que supervisiona, para as quais essa empresa do setor eletrônico representou uma melhoria sensível do salário, condições de trabalho, perspectivas de futuro: "Eu senti a diferença quando entrei aqui, lá era realmente como a linha de produção, não se tinha contato como se tem com nossos supervisores ou supervisionados. [...] As pessoas da 'Lou', da 'Valisère', a diferença de trabalho aqui mudou um tanto suas vidas." Citando seus irmãos, chefe de controle

\footnotetext{
Um acordo sobre a redução do tempo de trabalho, para compensar a passagem ao trabalho noturno e garantir a contratação de desempregados, foi assinado, em 1992, pelos sindicatos e promovido pelo Estado (o Primeiro Ministro se deslocara para reforçar o aspecto exemplar deste acordo).
} 
de estoque e chefe de equipe em duas empresas da aglomeração de Grenoble, "comparando minha antigüidade e a deles, eles dizem que realmente se tem sorte de trabalhar na HP". Seu estatuto de mãe solteira é bem aceito, propuseram-lhe o cargo de supervisora no retorno de sua licença-maternidade: "Não sei se é porque eu era solteira e então disponível ou o quê." Ela mantém vínculos pessoais com seu pessoal, fora do horário de trabalho: "Tenho contatos externos com meu pessoal, viagens, saidas, convidamo-nos mutuamente para ir em casa, uma vez por ano, reunimos todo o mundo, tanto os supervisores quanto os supervisionados, e saímos juntos para comer fora." Em seu trabalho, ela sabe anular o caráter dramático do procedimento de avaliação dos desempenhos, que é em si fonte de tensões ("eu utilizo um formulário padrão para todo o mundo") e, ao mesmo tempo, encaminhar para a enfermaria, para o serviço de pessoal ou, eventualmente, para um advogado os assalariados que têm problemas.

\section{COLOQUEM-ME SOZINHO NUM CANTO}

"Lembro de alguém em particular que, neste momento, sofre realmente de uma depressão, um homem, ele está numa fase de reconstrução completa de sua personalidade porque desmoronou completamente, não suporta mais essa vida em grupo, ele volta dizendo: "Coloquem-me sozinho num canto". Postos assim, aqui, não temos... Ele era supervisor e então, bom, desmoronou, eu não diria que a HP foi... enfim, constatamos mesmo, no departamento médico, que nunca é por causa da HP. As pessoas dizem: "Ah, ele desmoronou por causa de", não, mas a HP é, de vez em quando, a gota d'água que faz transbordar o copo, isso é certo [...]. O trabalho estava se tomando dificil de gerir porque era alguém de quem se exigia cada vez mais e que, finalmente, exigia cada vez mais de seus caras atrás, num determinado momento, começou-se a querer lhe passar um discurso no qual ele mesmo não acreditava. $\mathrm{E}$ como é uma pessoa profundamente honesta, foi ele que se demoliu. Ele não conseguiu mais passar a mensagem e logo foi ele que se despedaçou. É alguém que volta agora dizendo: "Quero ficar num canto..."Estão lhe procurando alguma coisa, mas não há nada! Há muitas pessoas que sofrem com isso, tem gente que precisa trabalhar sozinho. Você é um pouco introvertido, fechado. Aqui, mesmo quando você chega, é um grupo inteiro, é preciso dar "bom dia pessoal!" todos os dias. [...] Há momentos que, justamente para quem é tímido, são dificeis. Portanto, temos muita gente que trabalha, que já se sente forçada quando chegam porque, logo na chegada, suspiram... "tenho que suportar os outros durante oito horas", bom, é... quando você é alguém que prefere trabalhar tranqüilo em seu cantinho e que... e isso não quer dizer que sejam pessoas que fazem um mau trabalho ou que não sejam rentáveis, mas esse tipo de cargo não existe, tudo passa pelo grupo na nossa empresa [...]. Para um homem, começar a chorar não faz parte da cultura. Mesmo uma mulher que começa a chorar numa linha (de produção), levam-na a nós dizendo: "Bom, ela desabou..." Homens, bem, vimos alguns chorar na enfermaria, mas lhe asseguro que eles esperam terem entrado na enfermaria para chorar assim. É realmente assim: "O que é que está me acontecendo para chorar assim? Desculpe por ter feito isso na tua frente." [...] É a grande lata de lixo onde se coloca tudo lá dentre, lá atrás, um dia, ela transborda e, mais cedo ou mais tarde, bem, um dia isso explode no trabalho porque, uma manhã, o chefe lhe faz uma advertência, é a advertência que faltava e então é o fim. Eu tento passar a eles a mensagem dizendo: "Atenção, é preciso se preocupar com ele", é preciso evitar o olhar dos outros naquele momento, pois, quando você aparece no dia seguinte e que todo o mundo lhe diz: "Tá melhor?" é o que ocorre infelizmente! Você tem uma crise de nervos aqui, no dia seguinte, você tem trinta e cinco pessoas que passam por você: "Então, você está melhor?"” (Enfermeira). 


\section{Os usos dos diplomas "pela casa"}

Os princípios de responsabilização, de autonomia no trabalho, de autocontrole são também maneiras de reconhecer a legitimidade dos diplomas sem reconhecer o título que conferem. No caso dos assalariados de origem popular, a trajetória garante por si só a presença das qualidades tradicionalmente vinculadas à mãode-obra feminina (dedicação, afinco no trabalho, modéstia, minúcia, autoanulação). A presença de um pessoal "supertitulado" é verificada mesmo no caso das mulheres que ocupam postos de produção. Pode-se citar uma filha de agricultores oriunda de uma familia católica de muitos filhos, titular de um baccalauréat em Letras obtido como bolsista numa escola de ensino privado (ela tinha que fazer limpezas e tarefas braçais para pagar sua escolaridade), admitida como operária logo nos primeiros meses de abertura da fábrica. Após um ano de desemprego, separada de seu marido e tendo dois filhos pequenos para criar, ela foi contratada sem ter dito que havia feito o baccalauréat e iniciado os estudos de assistente social para ter mais chances de obter um emprego ao nível de brevet. Depois de dezessete anos na produção, graças à formação permanente, ela subiu para um posto de telefonista bilíngüe.

O esforço exigido é ainda maior para os funcionários e técnicos a partir do momento em que sua competência foi reconhecida e que estes são colocados em concorrência com os executivos. Assim, uma antiga técnica sem título (entrou na HP antes de ter obtido um BTS para o qual ela não chega a prestar nem mesmo a prova oral), foi encarregada, após um estágio nos Estados Unidos, de ensinar a engenheiros o modo de utilização de um produto do qual ela é uma das únicas especialistas nesta multinacional. Confrontada com homens seguros de si ("são pessoas que são formadas não apenas na técnica mas também no estado de espírito, são ensinadas a dizer 'eu sou bom, sou o melhor'”), ao pessoal da área comercial, a um público internacional ao qual ela se dirige em inglês, muitas vezes mais atento às inovações ligadas a esse produto, sua autoridade é constantemente questionada: uma falta de legitimidade escolar ("eu poderia ter feito uma classe préparatoire"), social (ela é filha de um motorista de ônibus que se tornou também instrutor) e "identitária" (uma mulher solteira numa carreira de homem) faz com que ela viva sua situação como impossivel.

\footnotetext{
"Eles achavam que eu era bastante pedagoga, meus colegas, eles me diziam: "Oh, você deveria se apresentar como instrutora." Então fui lá e fui aceita. $\mathrm{Na}$ verdade, eles não deveriam ter me aceito, porque o serviço de pessoal era contra. Mesmo assim, fui admitida no setor de treinamento e, com o passar do tempo, estou me dando conta quie o serviço de pessoal tinha razão: eu me adaptei muito mal, foi muito mal para mim lá. Foi quase a mesma história do 'baccalauréat', eu não tenho confiança em mim, pois, quando você está diante dos caras para formá-los, é preciso estar bastante seguro, e este não era o meu caso, portanto, não vivi muito bem a situação. Fui admitida e, logo depois, fui aos Estados Unidos para fazer um estágio. O curso não é como na escola, é pior. Você tem um grupo, você tem seis máquinas e doze pessoas. Na verdade, como tínhamos dificuldade em responder à demanda, tínhamos muitas vezes quatorze, dezesseis pessoas. Os cursos que eu dava duravam 5 semanas! Eu passava, portanto, 5 semanas sozinha, na minha sala, com meus 14 caras, porque eram só homens - eu tinha sido admitida, mas era a primeira mulher que eles admitiam e, na Europa, eu era a única [...] A aula se dividia sempre em duas partes: de manhã, teoria, e à tarde, o que a gente chama de "laboratório", são os trabalhos práticos;
} 
de manhã, explicava-se o funcionamento da máquina: nossas salas de aula têm todas um retroprojetor, e projetamos transparências, era eu quem criava a aula, era eu que escrevia minha aula. Preparar uma aula é loucura: eu estava sempre atrasada, eu entrava em pânico. São 5 semanas, 8 horas por dia, à noite, você vai então preparar seu material para o dia seguinte! Então, ao final de 5 semanas, é muito simples, eu estava doente! Estava morta, não agüentava mais... Porque, para fazer esse trabalho, as pessoas que se saem bem são pessoas que não se preocupam com nada, enfim, que têm um certo desligamento, que têm uma certa faculdade de se desligar daquilo que está acontecendo, que ficam recuadas, sei lá... E se você é um pouco... Em pedagogia, eu não era ruim, não era um problema de pedagogia que eu tinha. Não, quando eu explicava alguma coisa, os caras compreendiam bem... quando eu sabia (risada). É quando eu não sabia que a coisa se passava mal! Os outros colegas também não sabiam, mas eles nem ligavam para isso, diziam: "Oh, isso você não precisa saber", enquanto que eu fazia um bicho de sete cabeças das coisas que não sabia. Era preciso ensina 25 semanas [...]. Não suportei muito bem, no primeiro ano, era horrivel, então, no segundo ano, eu já estava começando a procurar outra coisa para fazer porque eu sentia que ia completamente... Durante o curso, era horrivel: de manhã, eu chegava, ia chorar no banheiro, e depois, como era a hora de ir para a aula, eu ia para a aula! Era horrivel! Eu tomava medicamentos, enfim, em resumo, não agüentava mais. Eles contrataram uma outra garota para o curso, e ela vinha de uma escola de engenharia, era engenheira. Eles a pegaram para trabalhar comigo justamente: éramos encarregadas dos mesmos produtos, dos mesmos cursos, eu tinha que formá-la. No final de seis meses, ela foi embora. Mas ela não agüentava mais, como eu: ela resmungava todo o tempo! (risada). Era realmente a dupla infernal!"

Outro exemplo tomado dentre as secretárias, a assistente de um diretor de departamento tem todos os atributos de uma pessoa que ocupa um cargo de confiança, cargo cuja função depende em parte da carreira do responsável para quem ela trabalha. Trata-se menos de realizar tarefas técnicas do que exercer com discrição um trabalho de comunicação, essencialmente em inglês (telefone, correio eletrônico), administrar a agenda de um gerente levado a viajar muito ("é uma coisa dificil quando se tem um chefe brilhante mas que é completamente desorganizado"), preparar reuniões com toda a equipe, substituir o chefe durante sua ausência. Um longo período de desemprego, a experiência de pequenos empregos (entrevistadora para um grande centro de compras, trabalhos temporários para um estudo europeu num organismo internacional, tradução assistida por computador) e sua trajetória familiar de filha de operário, titular de um diploma de língua obtido em 4 anos de estudo superior (maîtrise de langue), um ano passado na Inglaterra e um DESS (Diploma de Estudos Superiores Especializados, obtido com maîtrise + 1 ano) em economia do trabalho, explicam o fato de ter aceito ingressar na HP como secretária interina, de nivel 'baccalauréat', esperando o reconhecimento posterior de seus títulos.

"Fiquei quase um ano e meio desempregada, [...] cada vez que eu me apresentava para um cargo, o que acontecia, o que não dava certo era minha formação. Eu conseguia passar por todas as etapas, tinha várias entrevistas e, na última etapa, sempre havia alguma coisa que trancava, era sempre a formação; enchi o saco e me inscrevi na Ecco (empresa de estágios), e depois cheguei um dia na HP assim [...]. Um mês depois, o contrato terminou, e eu, no intervalo, continuava minhas buscas, $[. .$.$] e então, mais ou menos seis meses depois,$ voltaram a entrar em contato comigo dizendo: "Olha, tem uma vaga de secretária, sei que gostariam muito que você pegasse, então, venha ver." Foi assim, sem passar pelo serviço de pessoal, era um dos dois chefes para quem eu ia trabalhar que queria que fosse eu [...]; foi tudo bem, ele deu OK. Bom, eu disse para mim mesma: "Enfim, deu, maravilha." E de- 
pois, para maior segurança, passei no serviço de pessoal com meu curriculum, sem ter dito que eu tinha um DESS. E foi lá que, eu me lembro muito bem, a responsável do departamento pessoal me disse: "Para mim, eśtá fora de questão que você seja contratada", e então passei depois no setor de marketing, fui falar com eles, eu disse: "Bom, sinto muito, deu mas não deu." Em seguida, teve toda uma fase de negociação, eu estava sem trabalho. E então, no dossiê, está bem assinalado: "Me forçaram, eu contratei." Eu até compreendo a idéia deles de empregar pessoas que vão progredir depois, então ela me disse: "Estou absolutamente certa de que, quando você estiver aqui, você o fará, mas com relação a sua formaçāo, mais cedo ou mais tarde, você ficará frustrada." $\mathrm{E}$ foi mais ou menos o que aconteceu posteriormente, eu era então a secretária de dois departamentos. $\mathrm{E}$ é verdade que, dois anos depois, eu já tinha experimentado tudo no trabalho e estava realmente frustrada."

\section{O "fora do trabalho" no trabalho}

Para o médico trabalhista empregado pelo estabelecimento, a filosofia da empresa se resume na "idéia de promover as pessoas e de fazer com que possam administrar sua vida pessoal. É uma idéia muito personalista, excelente. Aqui não se deseja e não se quer assistir à pessoa [...]. É preciso admitir isso, cada um deve encontrar seu lugar num sistema que é formalizado por certos aspectos e que, para outros aspectos, é perfeitamente informal. Aquele que não encontra seu lugar tem dificuldade". De fato, o estresse foi várias vezes evocado pelos entrevistados que o relacionam com a ausência de plano de carreira. Cada um é levado insensivelmente a misturar trabalho e "fora do trabalho", a equipar seu domicílio como um anexo do seu escritório (telefone, fax, note book, impressora), ${ }^{8}$ mas sobretudo, devido às incertezas da vida profissional, a submeter vida familiar e tempo livre aos imperativos do cargo. Na seguinte passagem, uma jovem líder sindical, engenheira de pesquisa, de uma família de funcionários públicos parisienses e que fez grande parte de seus estudos no Exterior, evidencia como essa incerteza e essa avaliação permanentes podem produzir um afastamento do pessoal que envelhece ("o desgaste dos executivos"), uma dificuldade, para as mulheres, de tomar conta da família, e pode constituir, enfim, um obstáculo a um engajamento político ou sindical.

“Depois de um certo tempo, é verdade que há alguns executivos que têm mais de 50 anos. São pessoas que não puderam se reconverter, então hoje, não têm as competências de que HP necessita. Parece que já houve um caso de out-placement. Há casos de pessoas que não têm nada a fazer, como assim, que foram chutadas para escanteio em sua tarefa atual por serem considerados não competentes, e a gente se pergunta... Tem-se a impressão que esperam que essas pessoas tenham um colapso nervoso para fazer alguma coisa. Isso não é bem administrado e o problema é que todo o pessoal do gerenciamento deve raciocinar em prazo muito curto, porque eles têm objetivos a curto prazo, eles estão saturados pelos negócios [...]. Era mesmo uma espécie de reivindicação da parte da HP dizer: "Não adminis-

- Numa reportagem apresentada no inicio de 1996 pela M6 (televisão) no programa "Capital", vimos, por exemplo, um executivo da área comercial desta empresa obrigado a trabalhar em casa desde a supressão de várias agências comerciais no interior da França. Ele instalou seu escritório numa peça separada do resto de seu apartamento por uma divisória dupla e, quando está trabalhando, usa temo e gravata.

Termo em inglês, consagrado na linguagem empresarial francesa, que designa o esforço das empresas em recolocar no mercado de trabalho os empregados que não podem ser mais mantidos na empresa (nota da tradutora). 
tramos as carreiras porque não é necessário". Não há nenhum problema de recolocação para nossos executivos. Era mesmo algo que era dito alto e forte. Hoje, eles começam a se dar conta que seria necessário talvez que fossem capazes de ter planos de carreira para as pessoas. Ninguém tem plano de carreira. $\mathrm{E}$ quando você pede isso, isso me aconteceu, eu disse para mim mesma: deve haver especialistas, em algum lugar, que podem me ajudar a saber o que quero fazer da minha carreira, não era problema do serviço de pessoal. Cabia ao supervisor fornecer a assistência... (e para as mulheres), é preciso ser uma wonderwoman, com filhos que ficam um pouco largados, etc (isso acontece com muita freqüência nos Estados Unidos), para se ter efetivamente uma carreira, uma progressão, creio que a escolha é real, não quero fingir que não vejo isso; é uma deficiência e é difícil justamente com toda esta cultura de sessenta horas e este peso que se sente quando não se dá o máximo de si a HP, estamos num contexto psicológico muito difícil de suportar e creio que, pessoalmente, é preciso fazer uma escolha: ou não dedicar o tempo que se deveria à familia, ou então é preciso saber que sua carreira sofrerá as conseqüências... É uma forma de renúncia, quando eu estiver diante de uma familia, minha carreira ficará, eu mesma, minha carreira ficará atrás, isto cortará minha carreira. Manterei uma a atividade profissional seja como for, por muitas razōes, em caso de situação difícil e tudo o mais, porque eu acho que a independência das mulheres é algo... Eu sou muito sensivel a isso e quero sempre manter os meios de ser independente em caso de situação dificil e, para isso, é indispensável manter um pé na indústria, se relaxamos nesse contexto aí... Não podemos voltar se paramos de trabalhar três anos, está acabado. Três anos, a gente é completamente largado, três anos, a gente fica completamente largado no plano das competências, parar três anos significa não ter trabalho depois.

As pessoas têm muito medo de se lançar em ações do tipo líder do pessoal, porque tudo é individualizado, a fixação de objetivos, a evolução de carreira, a avaliação de desempenho, o aumento salarial, e tudo é extremamente dependente. Eu acabo de sofrer isso porque eu tinha más relações com meu supervisor [...]. Eu fui candidata nas eleições municipais, logo voltando da licença, lá para as eleições cantonais, é claro que eu não estava num estado fisico e nervoso brilhante, e eu emiendei na campanha das eleições municipais, e meu supervisor mudou completamente seu comportamento, era impossivel, eu não era mais confiável para ele, não era possível [...] eu trabalhava quatro dias ao invés de cinco e isso significava muito claramente trinta horas, eu realmente não fazia hora extra, não era possivel e, para ele, trinta horas era meio tumo, não chegava a quatro quintos, porque um executivo faz sessenta horas, um executivo está sujeito a tudo. Eu era alguém que fugia às cinco horas da tarde para exercer "minha segunda vida", como ele dizia..."

Para as mulheres, as exigências do celibato prolongado ou de gravidez adiada, quando elas têm responsabilidades profissionais, bem como as tensões que todos os assalariados sentem entre sua vida privada e as exigências de disponibilidade além do horário de trabalho, são particularmente ilustradas pelos casais formados entre assalariados (HP é apresentada, com humor, como a "maior agência matrimonial de Grenoble"), que compartilham os mesmos gostos, seja apenas pelo fato de terem sido selecionados segundo os mesmos critérios de formação e de expectativa de mobilidade social.

Pode-se tomar como base o exemplo do casal, secretária e técnico, oriundos de familias operárias espanhola e italiana. Tendo decidido continuar a trabalhar em turno integral, após o nascimento de seu segundo filho, a mulher é, desde sua volta, assistente de direção, "um papel de suporte administrativo a um dos gerentes e a todo o seu staff", um trabalho que mudou completamente sua ótica profissional: "Através deste cargo, eu tive a chance, é realmente uma chance, de poder ver o conjunto da organização, do início ao fim, partindo da locomotiva até o último vagão." 
Ao contrário do emprego de seu marido, recrutado dois ou três anos depois dela para a área de compras com um diploma de desenhista industrial, uma área onde a passagem a executivo está mais ou menos traçada, 0 interesse de seu trabalho depende da diversidade das tarefas e de sua disponibilidade: "No cargo que ọcupo, há muitas coisas que, talvez, não são escritas preto no branco, mas que são feitas pela pessoa que ocupa este cargo. É tipicamente esse gênero de função, as funções de secretariado, as raras funções de HP que se tornam aquilo que a pessoa quer fazer delas. É extraordinário. Se eu quisesse ter um trabalho rotineiro, poderia muito bem ocupar este mesmo cargo, no mesmo lugar, e fazer esse tipo de trabalho. A rotina, eu confesso que fujo disso. Ser dirigida naquilo que faço, também não gosto muito. $\mathrm{O}$ que eu gosto é de ter meu trabalho e me organizar como quero para fazê-lo e também tentar trazer coisas novas, isso corresponde exatamente àquilo que procuro. Não tenho nenhuma vontade de me tornar executiva. Atualmente, eu não vejo o que isso me acrescentaria." Ela tem o sentimento de ser um "elo de uma enorme corrente". É preciso ter espírito de equipe, saber comunicar, o que é facilitado pela disposição dos locais, "ninguém fica fechado na sua pequena redoma", e ser discreto. Sua função a coloca em contato com informações confidenciais, "são coisas que guardo para mim, [...] se eu sei certas coisas relativas ao futuro da divisão ou seja lá o que for, penso que faz parte do meu trabalho não dizer a ninguém, nem mesmo ao meu marido [...]. Eu represento um olho, um ouvido e dedos que batem à máquina, é tudo, é assim que é preciso ver as coisas, é a maneira mais certa de proceder".

Trabalhar na mesma empresa facilita, ao seu ver, a colaboração do casal para encarar de frente, junto, vida familiar e carreira profissional. $\mathrm{O}$ tempo passado em casa, pela manhã e, sobretudo, na volta do trabalho, exige uma disciplina familiar tão rigorosa quanto a disciplina dedicada durante o tempo de trabalho: "A gente tenta fazer o possivel para conciliar os imperativos familiares com os imperativos profissionais, a gente tenta se equilibrar entre os dois." Apesar de diferenças de horários, eles se obrigam habitualmente a fazer os trajetos juntos de carro, deixando as crianças na escola e na creche e depois buscando-as na volta. "Enquanto um está no banheiro com um, o outro deve fazer outra coisa, preparar comida, por exemplo, não existe especialização entre nós, se uma das crianças está com um pouco mais de vontade de ficar com o pai ou com a mãe, a gente faz em função das crianças, a gente se adapta de acordo com a vontade deles [...]; cada um entende perfeitamente as exigências que se pode ter, isso permite que nos organizemos se as crianças ficam doentes ou se há um imperativo em algum lugar. A gente sabe muito bem o que deve fazer. Penso que isso nos facilita muito a tarefa".

Várias vezes, quando um de seus filhos adoeceu, ela se organizou para poder trabalhar em casa: "Eu vinha pela manhä, tomava o trabalho do dia, pegava um note book e trabalhava em casa. Eu não estava no local de trabalho efetivamente, mas meu trabalho pôde avançar. Pude fazer coisas que eu nem sempre tenho tempo de fazer quando estou aqui." Ao inverso, aconteceu-lhe de vir ao escritório excepcionalmente no sábado, sem jamais perder, no entanto, o senso dos limites 
entre tempo de trabalho e vida de família: "É preciso saber onde se tem que parar".

As mulheres, talvez mais do que os homens, nas entrevistas, são sensiveis ao contraste entre a doação de si exigida de todos e a concorrência sistemática dos agentes de produção com jovens interinos, prontos a tudo para conservar seu cargo, ou dos executivos formados pela empresa com diplomados das Grandes Écoles cujas esposas, muitas vezes inativas, podem se encarregar da familia. A enfermeira faz espontaneamente a ligação entre a degradação das condições de trabalho e a patologia que ela pode observar no dia a dia: "Caímos cada vez mais em depressão, acho que são as pessoas que envelhecem; na produção, eu diria que as pessoas cansam, e isso se torna cansaço físico porque é duro, as linhas de produção se tornam cada vez mais difíceis. Giram muito com interinos, interinos que, mesmo que lhes digam "não tem emprego, etc.", em algum lugar sempre tem aquela pequena esperança, portanto, quando se tem 18-20 anos, se é interino e se trabalha, se dá duro, se faz com que, quando se dá duro, os outros sejam obrigados a dar duro, há um cansaço físico que se instala. E depois, os executivos caem cada vez mais em depressão, porque eles envelhecem, aos quarenta anos. Eu não sei se você viu a escada que está no nosso hall de entrada, mas, na verdade, a carreira na HP, realmente, a partir de quarenta anos, você está no alto da escada e depois... não estava previsto assim, mas é simbólico, é bem engraçado, sim, na verdade, esta escada estava prevista para estar contra uma parede [...] e como fizeram uma vitrine atrás, foi afastada e, finalmente, se tornou muito simbólica, de frente para o vazio..., poderíamos escrever em baixo: carreira HP."

\section{Notas da tradutora}

Baccalauréat: Na França, o primeiro dos graus universitários, sancionado por um diploma que marca o término dos estudos secundários.

CAP: Certificado de Aptidão Profissional, formação técnica ao nivel do ensino secundário.

Brevet: Na França, diploma ou certificado que sanciona uma formação, em nível secundário, de operário ou funcionário qualificado ou técnico.

BTS: Brevet de Técnico Superior

Classe Préparatoire: classe de preparação para acesso às Grandes Écoles.

Grande École: estabelecimento de ensino superior caracterizado por uma seleção de ingresso através de concurso ou de titulos, por um alto nível de estudos e por efetivos reduzidos. 